\title{
PRODUCTION OF PEACH GRAFTS UNDER HYDROPONIC CONDITIONS ${ }^{1}$
}

\author{
Produção de mudas de pêssego enxertadas em sistema hidropônico ${ }^{1}$
}

\author{
Aline das Graças Souza², Nilton Nagib Jorge Chalfun², Valdemar Faquin ${ }^{4}$, Ademária Aparecida de Souza
}

\begin{abstract}
The objective of the present work was to study the feasibility of producing Okinawa rootstocks and peach grafts using a hydroponic system. The study was conducted in two phases. The growth and development of Okinawa rootstocks under hydroponic conditions were determined in the first phase, and in the second phase, the viability of grafting production of peach cultivars Aurora and Diamante associated with different types of rootstocks. The parameters analysed were the time required for 60 to $75 \%$ plants to reach the stages of transplanting $(15 \mathrm{~cm}$ height) and grafting (4 to $6 \mathrm{~cm}$ stem diameter), the percentage of sprouting grafts determined 20 days after grafting, and the height of the shoots measured every 7 days until grafts were $40 \mathrm{~cm}$ high measured from the crown. Although $13 \%$ of the Okinawa rootstocks grown under hydroponic conditions presented undesirable genetic segregation characteristics, transplanting was reached at 30 days after transference (DAT) to hydroponic conditions and grafting at 61 DAT. Proximal pruning at $5 \mathrm{~cm}$ gave rise to grafts of $47.53 \mathrm{~cm}$ in height at 116 DAT, and both cultivar showed $100 \%$ graft sprouting with the cultivar Aurora presenting higher growth.
\end{abstract}

Index terms: Grafting, peach, rootstock 'Okinawa', nutrient solution.

\section{RESUMO}

Conduziu-se este trabalho, com o objetivo de estudar a viabilidade da produção de porta-enxerto 'Okinawa' e de mudas enxertadas em sistema hidropônico. O experimento foi conduzido em duas etapas. Na primeira etapa, pesquisaram-se o tempo de germinação e o desenvolvimento vegetativo das plantas do porta-enxerto 'Okinawa' e na segunda etapa a viabilidade de produção de mudas enxertadas de pêssego das cultivares 'Aurora' e 'Diamante', associada a diferentes tipos de desmama dos enxertos. As características avaliadas referiram-se ao tempo para que 60 a $75 \%$ das plântulas atingissem o ponto de repicagem (15 cm de altura) e o ponto de enxertia (diâmetro de 4 a $6 \mathrm{~mm}$ ) coletados semanalmente, a percentagem de pegamento da enxertia foi avaliada aos 20 dias após a enxertia e o crescimento em altura dos enxertos (brotos), tomadas semanalmente, até atingirem $40 \mathrm{~cm}$ de altura. Embora cerca de $13 \%$ dos porta-enxerto de 'Okinawa' tenham se apresentado com aparência arbustiva e ananicante, características impróprias ao futuro desenvolvimento normal das mudas, o ponto de repicagem dos porta-enxertos foi atingido aos 30 dias após transferência para solução nutritiva (DAT) e o ponto de enxertia aos 61 DAT. A desbrota a $5 \mathrm{~cm}$ foi a mais apropriada à propagação de mudas de pessegueiro, estando as mesmas prontas para a comercialização aos com 47,53 centímetros de altura aos 116 DAT e ambas as cultivares apresentaram índice de pegamento de $100 \%$, sendo que a cultivar Aurora apresentou maior crescimento.

Termos para indexação: Enxertia, persicultura, porta-enxerto 'Okinawa', solução nutritiva.

\section{(Received in june 16, 2009 and approved in may 4, 2010)}

\section{INTRODUCTION}

Prunus persica (L.) Batsch represents the eighth most important fruit crop worldwide. Most peaches and nectarines are consumed natural. In 2004, the global production of the $P$. persica exceeded 17.5 million tons (Food and Agricultural Organization - FAO, 2007), although the yield in Brazil was insufficient to supply the demands of the domestic market. Expansion of the area under cultivation by $P$. persica (estimated to be 23864 ha in Brazil; Agrianual, 2007) depends on the adoption of new technologies in the production of peach plantlets.
Peach trees can be propagated by seed germination, cutting or grafting. Growers commonly employ budding techniques on almond rootstocks and obtain grafted plantlets within 14 to 24 months (Fachinello et al., 1994; Chalfun \& Hoffmann, 1997; Tofanelli et al., 2001). A significant reduction in the time taken to obtain peach plantlets of a size appropriate for commercialisation could be achieved through the use of hydroponics, a technique that has been applied successfully in the propagation of many plants including woody and ornamental species, leafy vegetables, pre-basic seed potatoes and fruits such as strawberry and passion fruit (Mendes, 2007).

${ }^{1}$ Information contained in this paper is protected in part by patent titled "Water plants: the production process of rootstocks and fruit forest and ornamental seedlings in hydroponics" with the IP protocol number 0802792-7 registered by Universidade Federal de Lavras

2Universidade Federal de Lavras/UFLA - Departamento de Agricultura/DAG - Cx. P. 3037 - 37200-000 - Lavras, MG - alinedasgracas@yahoo.com.br ${ }^{3}$ Universidade Federal de Lavras/UFLA - Departamento de Agricultura/DAG - Lavras, MG

${ }^{4}$ Universidade Federal de Lavras/UFLA - Departamento de Ciência do Solo/DCS - Lavras, MG

5Universidade Federal de Lavras/UFLA - Departamento de Ciências Exatas/DEX - Lavras, MG 
Although the initial set up costs are high, hydroponic systems offer numerous compensatory advantages including rapid crop growth independent of climate and season, reduced infection by pests and diseases, increased productivity and improvement in quality of product (Faquin et al., 1996). Additionally, hydroponically grown plants can be produced with standardised characteristics, much of the cultivation process can mechanised and automated, the consumption of water is drastically reduced, and the usage of fertiliser can be optimised (Furlani et al., 1999).

The application of hydroponics to the production of certified peach grafts represents a possible alternative to conventional methods, but the feasibility of such a process requires detailed investigation. The objective of the present study was to evaluate the viability of production of Okinawa rootstocks and peach grafts under hydroponic conditions, and to determine the effects of pruning different portions of the rootstocks on the subsequent development of scion shoots.

\section{MATERIALS AND METHODS}

\section{Experimental site}

Experiments were conducted at the Hydroponics Unit of the Department of Soil Science located at the campus of the Universidade Federal de Lavras (Lavras,

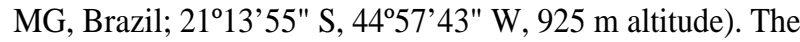
climate in the region is classified as Cwb according to Köppen criteria, i.e. temperate / mesothermal presenting dry winters with the average temperature of the warmest month below $22^{\circ} \mathrm{C}$ and at least 4 months averaging above $10^{\circ} \mathrm{C}$.

\section{Growth and development of rootstocks}

The first phase of the study was carried out between October 2007 and February 2008 with the aim of assessing the growth and development of Okinawa rootstocks under hydroponic conditions. The rootstocks originated from plant matrices grown at the Instituto Agronômico de Campinas (Campinas, SP, Brazil). Stones (endocarps) were removed from selected fruits, washed with tap water and dried in the shade. After opening the stones with the help of a workbench vice, the seeds were separated and left at $5^{\circ} \mathrm{C}$ for 35 days in order to break dormancy. Seeds were subsequently treated with the fungicide Captan $750 \mathrm{TS}^{\circledR}$ ( 2 g/kg seeds; Arysta LifeScience, São Paulo, SP, Brazil) and sown individually in plastic tubes $(20 \mathrm{~cm}$ high, $5 \mathrm{~cm}$ diameter) filled with vermiculite. The tubes were placed in appropriate supports and maintained in the green house with a daily supply of tap water for the complete germination period (51 days). Tubes containing $3 \mathrm{~cm}$ high seedlings were transferred to shallow hydroponic tanks located inside a green house. Nutrient solution, The tanks began to receive the nutritive solution described in the patent entitled "Water plants: the production process of rootstocks and fruit forest and ornamental seedlings in hydroponics" with the IP protocol number 0802792-7 contained in a $1000 \mathrm{~L}$ reservoir, was pumped to the hydroponic tanks at 15 min intervals and subsequently returned to the reservoir by gravity through special conduits. The bottom portion of each tube remained immersed in a 5 $\mathrm{cm}$ stream of nutrient solution during the entire duration of the experiment, thus ensuring a constant supply (by capillary action) of nutrient to the seedlings. The $\mathrm{pH}$ of the nutrient solution was maintained between 5.5 and 6.5 , and the concentrations of macro- and micro-nutrients were adjusted daily by measuring the electrical conductivity and adding appropriate amounts of stock salt solution. The nutrient solution was replaced completely every 30 days.

The experiment followed a randomised block design and lasted for 13 weeks. Three repetitions of 20 seedlings each were prepared with one plantlet per tube giving a total of 60 tubes. The parameters measured were the times required for the majority of plantlets (60 to $75 \%$ of the total number) to reach the transplanting (height of $15 \mathrm{~cm}$ ) and the grafting (stem diameter of 4 to $6 \mathrm{~cm}$ ) stages. Thus, every 7 days the height of each plant was determined (using a ruler calibrated in $\mathrm{mm}$ ) from the crown to the apex, and the diameter of each stem was measured at a position $10 \mathrm{~cm}$ from the crown with the aid of a pachymeter. The data collected were submitted to analysis of variance (F test), and the mean values were compared by regression analysis. Statistical analyses were conducted with the aid of SISVAR software (Ferreira, 2000).

\section{Development of peach grafts}

The second phase of the study involved grafting scions from two different peach cultivars, namely, Aurora and Diamante, onto hydroponically-grown Okinawa rootstocks and commenced when 60 to $75 \%$ of the latter had attained grafting stage (4 to $6 \mathrm{~cm}$ stem diameter). Inverted $\mathrm{T}$ budding was performed at a distance of $15 \mathrm{~cm}$ from the crown of the rootstocks. The grafting procedure was carried out during a morning period, and the root stock and scion were bound tightly together using transparent tape Twenty days after budding, the tape was removed and the rootstocks were pruned above the scion bud at proximal $(5 \mathrm{~cm})$, median and distal positions from the scion. The grafts were constrained to grow vertically and were maintained under the hydroponic conditions described 
above until they reached a size (40 cm height) considered appropriate for commercialisation. During this period the heights and stem diameters of the grafts were determined every 7 days as previously described.

The experiment was of a randomised design and arranged according to a split-plot in time scheme with three repetitions. The plots consisted of two cultivars and three weaning procedures ( $2 \times 3$ factorial scheme), whilst the sub-plots consisted of four evaluation times. Each repetition comprised three plants, with a single plantlet per tube, to give a total of 54 plantlets. The parameters determined were the percentage of sprouting grafts at 20 days after grafting (green grafts) and the height of the shoots (measured every 7 days until the plantlets reached $40 \mathrm{~cm}$ in height ). Mean values relating to the factor time were compared by analysis of variance and regression analysis, whilst mean values corresponding to the variables type of scion and pruning procedure were compared using Tukey test at the 5\% probability level. Values relating to the percentage $(x)$ of sprouting grafts were arcsin transformed $(\sqrt{x / 100})$ prior to statistical analysis.

\section{RESULTS AND DISCUSSION}

The heights and stem diameters of Okinawa rootstocks were significantly $(P<0.01)$ influenced by the time during which the plantlets were maintained in nutrient solution (Table 1). The seed-originated rootstocks presented excellent vegetative growth under hydroponic conditions, reaching an average height of $78.67 \mathrm{~cm}$ and a stem diameter of $5.73 \mathrm{~mm}$ within 84 days.

Out of the 60 plantlets evaluated, $60 \%$ reached transplantation stage (height of $15 \mathrm{~cm}$ ) just 30 days after transference (DAT) to hydroponic conditions whereas $75 \%$ of the plantlets reached the grafting stage (stem diameter of $4-6 \mathrm{~mm}$ ) at 61 DAT.

Medeiros \& Raseira (1998), working in the south of Brazil where the climatic conditions are admittedly different from those of the south of Minas Gerais, state that peach seeds must be planted in the field (or in seed beds) between April and May (and transplanted, if necessary, between July and August) in order for the plantlets to be ready for grafting between November and December, i.e. some 8 months after seed sowing. It is clear, therefore, that transplantation and grafting stages of peach rootstocks are attained very much earlier when hydroponics are employed in comparison with the conventional conditions favoured by commercial growers.

Junior et al.(2008), in study with rootstock peach, in which all the material was maintained in the house of vegetation, in plastic bags sanfonados containing as substratum mixture of Red Latossol + Plantmax ${ }^{\circledR} 3: 1 \mathrm{v} / \mathrm{v}$, enriched with P2O5 $\left(3.0 \mathrm{~g} \mathrm{dm}^{-3}\right)$, observed time for the doorgrafts reached five $\mathrm{mm}$ in diameter was 130 days of growth. In comparison to this work, or, under conditions hydroponic, there was an anticipation in 53 days of the diameter of rootstock.

Nunes et al. (2010) studying the rootstock (Prunus persica) cultivar Aldrighi which all the material was kept in a mist house in plastic bags gusseted containing five liters of the substrate made up of clayey land coming from a typical dystrophic Red Podzol, sand (particle size between 0.6 and $1.0 \mathrm{~mm})$ and decomposed black acacia residue $(1: 1: 1$, $\mathrm{V}: \mathrm{V} . \mathrm{V})$, at that moment, the root system of the seedlings was immersed in a hydroalcoeolic solution hidroalcoeólica containing a concentration of $1.5 \mathrm{~g} \mathrm{~L}^{-1}$ of indolbutiric acid (AIB) for a 10 second period, it was found that the time for the rootstocks to reach the grafting point was of 360 days of growth. In comparison to the present work, that is, under hydroponic conditions, there was a anticipation of 276 days (Table 1).

Table 1 - Mean heights and stem diameters of Okinawa plantlets following transfer of pre-germinated seeds to hydroponic conditions.

\begin{tabular}{ccc}
\hline $\begin{array}{c}\text { Days after transfer } \\
\text { (DAT) to hydroponic } \\
\text { conditions }\end{array}$ & \multicolumn{2}{c}{ Variables } \\
Height $(\mathrm{cm})$ & $\begin{array}{c}\text { Stem diameter } \\
(\mathrm{mm})\end{array}$ \\
\hline 1 & 4.15 & - \\
7 & 7.00 & - \\
14 & 9.33 & - \\
21 & 13.67 & 2.13 \\
28 & 18.33 & 2.50 \\
35 & 22.00 & 2.87 \\
42 & 23.67 & 2.93 \\
49 & 26.60 & 3.00 \\
56 & 32.76 & 3.43 \\
63 & 40.00 & 3.97 \\
70 & 51.00 & 4.63 \\
77 & 65.33 & 5.03 \\
84 & 78.67 & 5.73 \\
\hline $\mathrm{MS}^{(1)}$ & $1530.0342^{* *}$ & $4.1778^{* *}$ \\
$\mathrm{CV} \%$ & 11.13 & 6.45 \\
\hline
\end{tabular}

${ }^{(1)}$ Mean square. ${ }^{(2)}$ Coefficient of variation

**Statistically significant according to the $\mathrm{F}$ test $(P<0.01)$. 
Approximately $13 \%$ of the Okinawa rootstocks grown under hydroponic conditions presented shrub- and/ or dwarf-like appearances, characteristics that are considered unsuitable for field cultivation. Such genetic heterogeneity is, however, a genetic determinant commonly found in fruit trees (Masseron, 1989).

In the second phase of the study, the success rate of graft sprouting achieved on the Okinawa rootstocks was $100 \%$ and statistical analysis was, therefore, unnecessary. This result corroborates previous reports (Chalfun \& Hoffmann, 1997) that a high sprouting rate (> 90\%) could readily be achieved when peach grafts were grown under suitable conditions.

In the present study, pruning the grafted rootstocks at the position distal from the scion bud delayed further growth such that only $11 \%$ of pruned grafts continued normal development. Distal pruning was thus removed from the statistical analysis outlined below.

In respect of the variable height of shoots, it was possible to demonstrate a significant interaction between type of scion $x$ time (Figure 1A) and between pruning position $x$ time (Figure 1B). The mean heights of grafts produced with the Aurora cultivar were consistently higher than those of the Diamante counterparts, and the differences were statistically significant $(P<0.05)$ at 126 and 133 DAT. Moreover, grafts that had been pruned at the median positions of the rootstocks were significantly $(P<0.05)$ larger at all evaluation times than those pruned at the proximal position ( $5 \mathrm{~cm}$ from the scion bud), and they exhibited a growth rate that followed a linear rather than a quadratic model with time.

According to Ordinance No. 173 of 27 may 1984 laying down minimum standards for the production, transportation and marketing of seedlings of peach. According to Article I of this ordinance, the plants should provide a main stem with at least $40 \mathrm{~cm}$ measured from the neck of the plant, as quoted by Finardi (1998).Considering that the original rootstocks were $15 \mathrm{~cm}$ in height, grafts needed to attain a height of $25 \mathrm{~cm}$, measured from the scion bud, in order to comply with this regulation. Aurora and Diamante grafts attained mean heights of $25 \mathrm{~cm}$ from the scion bud at 128 and 135 DAT (estimated from the growth models), respectively.
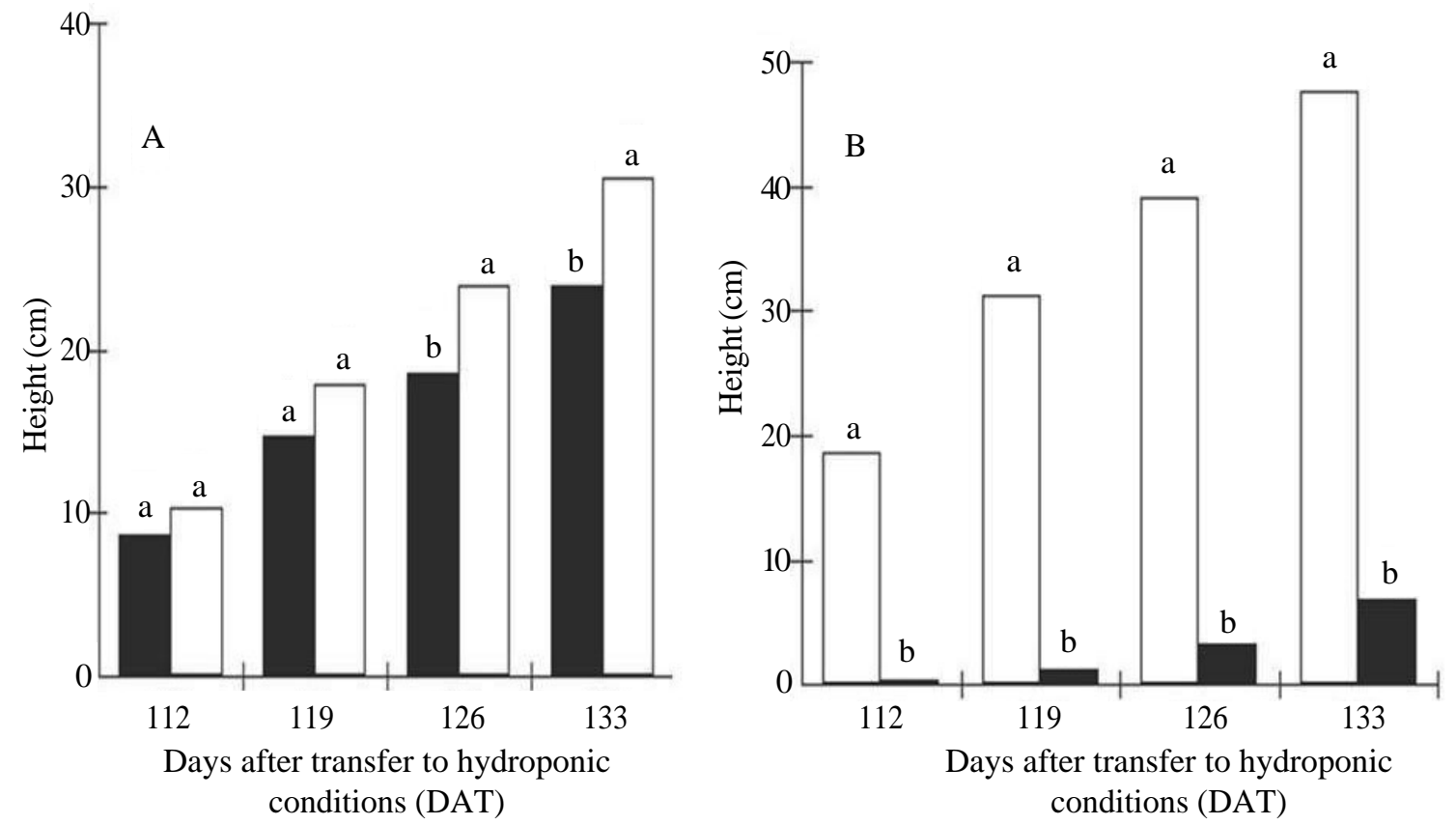

Figure 1 - Mean heights of peach grafts grown under hydroponic conditions as a function of the number of days after transference (DAT) to hydroponic conditions. Two different scions derived from Aurora $\square$ and Diamante $\mathbf{\square}$ cultivars are shown in A, and two methods of pruning of the upper segment of the rootstocks, namely, at the proximal position (5 cm from the scion bud) $\square$ and at the median position $\mathbf{\square}$, are depicted in B. Bars bearing dissimilar superscript letters are significantly different $(P<0.05)$ according to Tukey test. 
Additionally, grafts submitted to proximal pruning reached $25 \mathrm{~cm}$ height at 116 DAT (estimated from the growth model) and, hence, at this time the grafts already presented the characteristics required for commercialisation.

During the second phase of the study, all peach grafts were maintained under hydroponic conditions until their heights and diameters attained the values specified by the Ministry of Agriculture Ordinance $n^{\circ} 173$ of 27 may 1984, (Finardi, 1998) after which they were transplanted into perforated $3 \mathrm{~L}$ polyethylene tubes containing appropriate substrate, and later into the field. The vegetative development of such grafts was followed systematically and no visible signs of stock-scion incompatibility were observed within the first three months following transfer to field conditions.

\section{CONCLUSIONS}

Although $13 \%$ of the Okinawa rootstocks grown under hydroponic conditions presented undesirable genetic segregation characteristics, most reached the transplanting and grafting stages at 30 and 61 DAT, respectively. Proximal pruning (at $5 \mathrm{~cm}$ from the scion bud) resulted in grafts with an estimated mean height of more than $40 \mathrm{~cm}$ (measured from the crown) at 116 DAT, and were thus ready for commercialisation. The development of grafts obtained with Aurora scion was better than that of grafts with Diamante scion. The hydroponic system clearly represents a feasible technique for the production of commercial peach grafts.

\section{ACKNOWLEDGEMENTS}

The authors wish to thank FAPEMIG and CNPq for financial support.

\section{REFERENCES}

AGRIANUAL. Anuário da agricultura brasileira. São Paulo: FNP Consultoria e Comércio, 2007. 442p.

CHALFUN, N.N.J.; HOFFMANN, A. Propagação do pessegueiro e da ameixeira. Informe Agropecuário, Belo Horizonte, v.18, n.189, p.23-29, 1997.

FACHINELLO, J.C.; HOFFMANN, A.; NATCHTIGAL, J.C. Propagação de plantas frutíferas de clima temperado. Pelotas: UFPel, 1994. 168p.

FAQUIN, V.; FUTINI NETO, A.E.; VILELA, L.A.A.Produção de alface em hidroponia. Lavras: UFLA, 1996. 51p.
FERREIRA, D.F. Análise estatística por meio do SISVAR para Windows 4.0. In: REUNIÃO ANUAL DA REGIÃO BRASILEIRA DA SOCIEDADE INTERNACIONAL DE BIOMETRIA, 45., 2000, São Carlos. Anais... São Carlos: UFSCAR, 2000. p.255-258.

FINARDI, N.L. Método de propagação e descrição de porta-enxertos. In: RASEIRA, M.C.B.; MEDEIROS, C.A.B. A cultura do pessegueiro. Brasília: Embrapa-SPI, 1998. p.100-129.

\section{FOOD AND AGRICULTURE ORGANIZATION.}

Melocotones y nectarinas: producción, área y rendimiento. Available at: $\leq$ http://faostat.fao.org/sited $567 /$ DesktopDefault.aspx?PageID=567\#ancor $>$. Accessed in: 27 Feb. 2009.

FURLANI, P.R.; SILVEIRA, L.C.P.; BOLONHEZI, D.; FAQUIN, V. Cultivo hidropônico de plantas. Campinas: Instituto Agronômico de Campinas, 1999. 52p. (Boletim técnico, 180).

JUNIOR, A.W.; SILVA, J.O.C.; SANTOS, E.M.; PIMENTEL, L.D.; NEGREIROS, J.R.S.; BRUCKNER, C.H. Ácido giberélico no crescimento inicial de mudas de pessegueiro. Ciência e Agrotecnologia, Lavras, v. 32, n. 4, p. 1035-1039, jul./ago., 2008.

MASSERON, A. Lês porte-greffe pommier, poirier et nashi. Paris: Centre Techhnique Interprofessionnel dês Fruits ef Legumes, 1989. 297p.

MEDEIROS, C.A.B.; RASEIRA, M.C.B. A cultura do pessegueiro. Brasília: EMBRAPA-SPI, 1998. $28 \mathrm{p}$.

NUNES, J.L. da S.; SOUZA, P.V.D. de; MARODIN, G.A.B.; FACHINELLO, J.C. Interação entre fungos micorrízicos arbusculares e ácido indolbutírico sobre o desenvolvimento vegetativo de plântulas do portaenxerto de pessegueiro 'Aldrighi'. Ciência e Agrotecnologia, Lavras, v.34, n.1, p.80-86, jan./fev., 2010.

TOFANELLI, M.B.D.; CHALFUN, N.N.J.; HOFFMANN, A.; CHALFUN, A.J.R. Capacidade de enraizamento de estacas lenhosas e semi-lenhosas de cultivares de pessegueiro. Ciência e Agrotecnologia, Lavras, v.25, n.4, p.840-847, 2001. 